\title{
EVIDENT OPDRAGELSESBEHANDLING
}

\author{
Et antropologisk blik på et evidensbaseret behandlingsprogram
}

\section{LOUISA ELLEN HENRIKSEN}

Behandling er blevet et bredt benyttet svar på mange og forskelligartede sociale problemer i dagens Danmark, og den såkaldte evidensbaserede behandling bliver af mange anset som særlig god. Det, der ligger i begrebet evidensbasering, er efterprøvning og dermed evidens for effektivitet. I de seneste år er evidensbaserede programmer især blevet udbredt inden for behandlingen af udsatte og utilpassede børn og unge.

I foråret 2012 udførte jeg i forbindelse med mit kandidatspeciale et feltarbejde, hvor jeg fulgte behandlingsprogrammet „Multidimensional Treatment Foster Care" (MTFC) over knap fem måneder. MTFC er et af de evidensbaserede programmer, der er blevet introduceret i det danske socialarbejde i løbet af det seneste årti. Det er kendetegnende for evidensbaseret behandling, at der er fokus på metodestringens, hvilket er tydeligt i MTFC, da programmet er manualbaseret. I løbet af mit feltarbejde lavede jeg deltagerobservation blandt de professionelle og deltagerne i behandlingsprogrammet, foretog interviews og studerede programmets manualer og retningslinjer. Dataindsamlingen bestod hovedsageligt af deltagerobservation med fokus på den observerende del og af samtaler og semistrukturerede interview med fokus på deltagernes oplevelser og forståelser af programmet og dets metoder. Empirien er samlet blandt 12 træningsforældre, 9 unge MTFC-indskrevne, 5 biologiske forældre, 1 tidligere MTFC-ung og behandlingsteamet bestående af behandlingskoordinator, 3 familieterapeuter, 1 ungeterapeut og 3 færdighedstrænere (rollerne beskrives nedenfor). Manualbaseringen i programmet betyder, at specifikke anvisninger følges for at opnå en behandling, der er udført præcis som forskning viser det mest effektivt i behandlingen af målgruppen af udsatte unge. De unge i MTFC får for eksempel dagligt uddelt point for ,god opførsel“ eller får frataget privilegier for det modsatte. Denne behavioristisk funderede metode, som jeg forklarer nærmere nedenfor, benyttes, da den i tidligere studier har vist sig at være effektiv. 
Evidensbaseret social behandling er interessant at undersøge antropologisk, fordi det er et relativt nyt fænomen i Danmark indført sidst i 1990'erne, og fordi det er et tankesæt, som ikke umiddelbart spiller sammen med de behandlingstraditioner, der ellers har eksisteret på området. Socialt arbejde har i høj grad haft fokus på relationer, nærvær og en forståelse mellem udsat barn og „behandler“. Selve betegnelsen behandling indebærer, at der iværksættes et forløb med formålet at ændre noget eller nogen til det bedre. Ofte har socialarbejdere imidlertid vægret sig ved at målsætte forandring, da fokus har ligget på socialpædagogik og relationsarbejde. Forskellige behandlingsformers karakter varierer afhængigt af de teorier, der danner grundlag for behandlingens metode. Netop behavioristiske tilgange, som man finder i mange evidensbaserede behandlingsprogrammer, har været lagt på hylden, efter at det danske socialområde bevægede sig bort fra konsekvenspædagogik og hen imod et fokus på socialpædagogik (Gilliam \& Gulløv 2012). Så hvorfor denne nye interesse for behavioristisk adfærdsregulering $i$ sociale behandlingsprogrammer? Hvad sker der, når denne mere „stringente“ form for socialt arbejde implementeres i praksis, og hvordan kan vi forklare nogle af de udfordringer, som disse behandlingsprogrammer medfører? Med afsæt i feltarbejdet blandt brugere og udøvere af MTFC-programmet er det artiklens formål at belyse bevæggrundene for evidensbaseret adfærdsregulering samt nogle af de karakteristiske problematikker, denne form for behandlingsarbejde indebærer. Artiklen vil følgelig argumentere for, at det sociale arbejde i et behandlingsprogram rummer en kompleksitet, der ikke problemfrit kan rummes i en kausal behandlingsformel.

\section{Evidensbaseret socialarbejde}

Ideen om evidensbaserede interventioner stammer fra det medicinske fagområde, hvor systematisk søgen efter effektiv behandling udgør en veletableret tradition med en metodologisk bekendelse til randomiserede kontrollerede forsøg (RCT) (Wampold 2001). Et RCT-studie opdeler undersøgelsessubjekter i mindst en interventionsgruppe og en kontrolgruppe. Interventionsgruppens subjekter modtager den intervention, der ønskes undersøgt, mens subjekterne i kontrolgruppen modtager den form for intervention, man ønsker at sammenligne med (Rieper \& Hansen 2007:21). Sammenligningsgrundlaget kan være en anden type intervention eller en placebo. Allokeringen til de to forskellige grupper i et RCT-studie er randomiseret, hvilket skal eliminere bias i udvælgelsen og sikre, at det eneste signifikante karakteristikum, der adskiller grupperne, er den intervention, man undersøger. Således sammenligner man effekten i de to grupper (ibid.). Med den hensigt at gøre velfærdsinterventioner mere effektive har interessen for evidens 
spredt sig til socialt arbejde og behandlingsformerne i dette felt. Det sociale område i Danmark kom under stigende finansielt pres i slutningen af 1990'erne, og dette pres krævede et fokus på prioritering, hvor evidensbaseret dokumentation blev set som en måde, hvorpå resultater bedre kunne dokumenteres og monitoreres (Krogstrup 2011:65). Evidensbasering handler om at udarbejde politik, praksis og forvaltning med afsæt i en akkumuleret viden om, hvilke indsatser der har størst mulig effekt. Den politiske interesse er, at man vil behandle folk i den sociale sektor effektivt med øje for det finansielle pres, som sektoren er underlagt. De britiske socialforskere Mel Gray, Debbie Plath og Stephen Webb lægger vægt på nødvendigheden af forudsigelige resultater $\mathrm{i}$ evidensbaseret socialt arbejde (Gray, Plath \& Webb 2009:9). RCT-studier kræver, at den undersøgte intervention er veldefineret, standardiseret og reproducerbar, og at den er udført på eksakt samme vis på hver deltager. Hvis dette skal være muligt i en social intervention, skal fremgangsmåden og metoderne i interventionen beskrives og følges stringent. Netop dette skaber et behov for manualisering af det sociale arbejde. I manualiseringen ligger en forestilling om, at praksis kan løsrives fra kontekst, gennemprøves og derefter duplikeres $i$ andre lignende sammenhænge med andre mennesker. Dette er ikke udelukkende en teknisk tilgang, men rummer også en udpræget positivistisk anskuelse af socialt arbejde. Forudsigelseselementet i evidensbaseret behandling synes at kræve, at man kender årsagssammenhænge og behandlingseffekt ud fra en forudbestemt beregning. Positivismens objektivistiske videnskabsideal forudsætter, at ethvert subjektivt element elimineres, men subjektive fænomener som hensigt og betydning er svære at undgå i sociale interventioner, der handler om menneskelig udvikling og socialt samspil.

\section{Multidimensional Treatment Foster Care}

MTFC er et af de behandlingsprogrammer, der fremhæves som evidensbaseret. Det er et manualbaseret program målrettet unge med emotionelle og/eller adfærdsmæssige problemer. Programmets manualbasering henviser til, at programmet er beskrevet detaljeret i en række manualer, der anviser, hvorledes behandlingen skal gennemføres, så den følger en efterprøvet metode, der har vist sig effektiv. De unge, der bliver indskrevet i MTFC, har så alvorlige adfærdsmæssige eller emotionelle problemer, at de alternativt til MTFC ville blive anbragt på en institution. Behandlingen af denne målgruppe har længe været et omdiskuteret emne både politisk og på praksisplan, og MTFC er som et bud på en effektiv intervention blevet vel modtaget og har fået bred politisk opbakning.

Et behandlingsforløb i MTFC varer cirka et år og involverer en midlertidig anbringelse af den unge i en træningsfamilie. Træningsfamilien består af en familie/ 
et forældrepar, som har gennemgået plejefamiliekursus og MTFC's træningsfamiliekursus. Behandlingen har den unge i centrum og udfolder sig derudover mellem træningsfamilien, et MTFC-team og forældremyndighedsindehaverne, dvs. de unges adoptiv- eller biologiske forældre. MTFC-behandlerteamet omfatter behandlingskoordinator, familieterapeuter, ungeterapeut, færdighedstræner og træningsfamilien. Behandlingskoordinator er overordnet programkoordinator. Familie- og ungeterapeuter gennemfører terapi med henholdsvis forældremyndighedsindehaverne og den unge. Færdighedstræner er en art rollemodel for den unge og træner dennes sociale færdigheder. Træningsfamilien er den plejefamilie, hvor den unge er anbragt. Alle i teamet benytter manualbaserede metoder og har hver sin manual. Ud fra disse manualer sørger teamet for at gennemføre behandlingsforløbet med terapi, vejledning og overvågning af den unge, træningsfamilierne og forældremyndighedsindehaverne. Overvågningen af den unge består blandt andet $\mathrm{i}$, at konkret positiv eller negativ adfærd fra den unges side dagligt bliver anført $i$ et skema. Målet med MTFC er at give den unge færdigheder til at lykkes i familien, skolen og fritidslivet. I forlængelse heraf er det en målsætning at give den unge nye redskaber til at håndtere forskellige adfærdsmæssige problematikker. Programmet integrerer den unges forældre i behandlingen ved brug af familieterapi, da det ønskede resultat af interventionen er, at den unge kan vende hjem og bo hos sin biologiske familie eller andre forældremyndighedsindehavere efter indsatsen. MTFC er baseret på en teori om, at det er mest effektivt at behandle unge med adfærdsvanskeligheder i det miljø, de skal kunne fungere $i$, dvs. som oftest $\mathrm{i}$ et nærmiljø og i en familiesammenhæng (Fisher \& Chamberlain 2000:156). Det er her, træningsfamilien bliver et primært led i behandlingsarbejdet i MTFC. Træningsforældrene skal have den unge MTFC-deltager boende hos sig under hele behandlingsforløbet. Deres rolle er at introducere den unge til deres families vaner og hverdagspraksis ved at integrere den unge mest muligt i deres familieliv. De skal fungere som en form for eksempler på „korrekt opførsel“ $i$ et dagligt familieliv. Træningsforældrene skal dog gøre dette inden for rammen af MTFC's metoder. De skal implementere programmets metode og værktøjer i den unges dagligliv. På denne vis udgør behandlingen en bevægelse væk fra institutionstankegangen og hen mod en mere helhedsorienteret tilgang, hvor inddragelse af familien ses som afgørende for den unges problematikker og succeser.

Træningsfamilier kan sammenlignes med plejefamilier, i og med at de skal have en ung boende hos sig og inkludere den unge i deres familieliv. Bortset fra denne lighed adskiller træningsfamilierne sig grundlæggende fra andre plejefamilier på grund af MTFC-programmets særlige metode. Anbringelsen i MTFC er altid midlertidig og betragtes som et træningsforløb med det mål at kunne sende den 
unge tilbage til sine forældremyndighedsindehavere efter 9-12 måneder. Mere specifikt er målet at skabe stabilitet og mindske uhensigtsmæssig adfærd som for eksempel kriminalitet eller antisocial adfærd gennem adfærdsregulering. Behandlingsprogrammet specificerer forventningerne til den unges adfærd og skaber således en slags formel for „god opførsel““.

Den unge optjener point, hvis han/hun lever op til programmets forventninger til adfærd. Pointene bliver gennem hele behandlingsforløbet givet af træningsforældre og af forældre i de dage, den unge befinder sig hjemme. Pointene bruges som en måde at give belønning og sanktioner på for det, der regnes for henholdsvis prosocial adfærd og problematisk adfærd. Til at holde styr på de optjente point $\mathrm{i}$ MTFC benyttes pointskemaer. Et almindeligt eksempel er vist i figur 1.

\begin{tabular}{|c|c|c|c|c|}
\hline \multicolumn{5}{|c|}{ Skoledag - Niveau 1} \\
\hline \multicolumn{2}{|l|}{ Navn: } & \multicolumn{3}{|l|}{ Dato: } \\
\hline POINT & $\begin{array}{l}\text { TING DER SKAL GøRES FOR AT } \\
\text { OPTJENE POINT }\end{array}$ & BONUS & TAGET & IALT \\
\hline 10 & OP TIL TIDEN & & & \\
\hline 10 & KLAR OM MORGENEN & & & \\
\hline 10 & MORGENRENGØRING & & & \\
\hline 5 & GÂR I SKOLE & & & \\
\hline 1/time & MEDBRINGER SKOLEKORT & & & \\
\hline 2/time & ADFÆERD I TIMEN & & & \\
\hline 10 & SKOLEKORTBONUS & & & \\
\hline 20 & LEESE OG STUDERE & & & \\
\hline 10 & PLIGTER I HJEMMET & & & \\
\hline 15 for kl. 12 & INDSTILLING / MODENHED & & & \\
\hline 15 efter kl. 12 & INDSTILLING / MODENHED & & & \\
\hline $2-10$ & TILBYDER SIN HJFELP & & & \\
\hline $5-10$ & EKSTRA PLIGTER I HJEMMET & & & \\
\hline 10 & I SENG TIL TIDEN (i gàr aftes) & & & \\
\hline & IALT FOR DAGEN: & & & \\
\hline
\end{tabular}

Figur 1. MTFC-pointskema.

Skemaerne indeholder forskellige punkter, der beskriver den unges forventede daglige aktiviteter og adfærd. Her ses det, hvilke punkter der indgår i opfattelsen af ,god opførsel“, for eksempel at stå op til tiden eller at lave lektier. Pointskemaet tilpasses løbende den unge, så det passer til hans/hendes specifikke vanskeligheder med at efterleve forventet eller ønsket opførsel. Hvis den unge eksempelvis har haft svært ved at tale pænt, laves et punkt på skemaet, der hypotetisk set kunne hedde „taler pænt til andre“. Det er således et skema for forventet og dermed passende eller prosocial opførsel. Som generelle punkter forventes det, at en ung 
i sin daglige omgang med familie, skole og andre er punktlig (står op til tiden og er klar om morgenen), hjælpsom (hjælper med rengøring og pligter), høflig (har en god adfærd og indstilling) og laver sine lektier. MTFC er et komplekst behandlingsprogram, der indeholder flere lag, end der er plads til at uddybe her, men i sin helhed er programmet bygget op omkring denne metode, der skal gøre det klart for den unge, hvordan han/hun forventes at opføre sig, og motivere til efterlevelse med anerkendende point. Pointsystemet i MTFC bygger på undersøgelser, der har vist, at unge med adfærdsproblemer er mindre modtagelige over for sociale belønninger som voksenanerkendelse end andre unge, men at de til gengæld kan lære på lige fod med jævnaldrende, hvis mere håndgribelige belønninger som for eksempel gaver, privilegier eller point benyttes som motivation. På samme måde viser forskningen, at unge med adfærdsvanskeligheder ikke responderer lige så effektivt på social misbilligelse, som de gør på håndgribelige tab af point og privilegier. MTFC's behavioristiske fremgangsmåde er på denne vis bygget på studier og senere afprøvet igennem RCT-forsøg, hvilket danner grundlag for betegnelsen evidensbaseret behandling.

\section{Stimuli og respons - ellers får jeg ikke mine point}

Så langt så godt. De unge får tildelt point, og den tilsigtede indlæring virker også til en vis grad i praksis. Under mit feltarbejde i behandlingsprogrammet fortæller Anton, en af de anbragte drenge i MTFC, mig en dag om sine tanker om programmets retningslinjer, mens vi venter på, at han skal til samtale med MTFC-teamets ungeterapeut:

'Ja, og så skal jeg lige huske det der med ikke at tale så hårdt. Du ved ... man skal tale pænt og det.' Jeg spørger hvorfor. Anton kigger på mig med løftede øjenbryn og ryster lidt på hovedet af mit spørgsmål. 'Ja, fordi ellers får jeg jo ikke mine point, vel?'

Anton taler pænt og får sine point. Men spørgsmålet er, hvilke tanker og bevæggrunde der følger Antons beslutning om at handle i overensstemmelse med pointskemaet. I MTFC tænkes der konstant ud fra adfærd, som på mange måder også er mere målbar end for eksempel emotionelle karakteristika. MTFC har på denne måde en klassisk behavioristisk tilgang til behandlingen af de anbragte unge. Behaviorismens nok mest kendte eksempel er den russiske psykolog I.P. Pavlovs indlæringsforsøg med hunde. Pavlov iagttog, hvordan hunde savler, når de er sultne og bliver præsenteret for godbidder. Hvis en godbid præsenteres for hundene i kombination med anden stimuli som for eksempel en bestemt lyd, begynder hundene efter en periode at savle alene ved præsentationen af lyden. 
I forlængelse af Pavlovs studie udførte den amerikanske psykolog B.F. Skinner forsøg med rotter. Skinner anbragte rotter i en særlig type kasse, hvor de lærte at trykke på knapper for at modtage en foderpille, belønning, eller for at undgå et elektrisk stød, straf. Denne indlæringspsykologis teori er således, at det lærende individ efterkommer de præsenterede stimuli med respons eller reaktioner, der er indlært med ydre stimuli og derfor mere eller mindre fastlagt uafhængigt af vedkommendes vilje. Ud fra dette perspektiv forsøger MTFC-behandlingen at lære Anton og de andre unge at udvise en indlært adfærd frem for at lære dem at bestemme indholdet af deres handlinger ud fra egne formål og værdier. Sagt på en anden måde lærer de unge i behandlingsprogrammet principielt ikke at opføre sig som socialt forventet af moralske, hensynsmæssige eller samfundsopretholdende årsager, som man måske ville have fokus på i andre opdragelsesmæssige sammenhænge, men fordi de bliver motiveret af point. Som udgangspunkt er det også netop, hvad den forudgående forskning peger på som effektivt: at håndterbare konsekvenser som point fungerer bedre for denne målgruppe af udsatte unge. Men virker det så, som formlen foreskriver? Behaviorismen er en pædagogisk tilgang, der udelukkende baserer sig på målbar adfærd, og som passer ind i de aktuelle styringspolitiske forestillinger, hvor sociale indsatser gerne skal være baseret på evidensbaseret viden. Programmets effektivitet er angiveligt evident, men der findes faktisk endnu ingen evaluering eller måling af programmet i Danmark. Mit feltarbejde pegede imidlertid også på en mere kompleks årsag-virkningssammenhæng i behandlingen end stimuli-respons-formlen.

\section{Stimuli og reflekteret respons}

I antropologien findes der ikke den store tradition for at beskæftige sig med adfærd med en behavioristisk vinkel. Antropologer skriver ganske vist om handlinger og intentioner, men sprogbrugen i adfærdsteori er anderledes end den antropologiske. Den stammer fra psykologi og psykiatri, hvor adfærd tilhører en bestemt genre. For at illustrere forskellen kan vi, som Thomas Hylland Eriksen (2001) gør det i sin introduktion til antropologi, skelne mellem begrebet handling og det relaterede begreb adfærd: „Adfærd refererer til observerbare begivenheder, der involverer mennesker eller dyr, hvor handling [...] indebærer, at aktørerne kan reflektere over det, de gør" (op.cit.48). Den kausale formel i MTFC bygger på, at det lærende individ efterkommer de præsenterede stimuli med respons, der er indlært med ydre stimuli og derfor mere eller mindre fastlagt uafhængigt af vedkommendes subjektivitet. Det er observerbare kausalitetssammenhænge. Men i antropologien ser vi, som Eriksen påpeger, i højere grad på ageren, i og med at vi ud over at interessere os for, hvad folk gør, også interesserer os for, hvad de mener med det, 
de gør. Jeg forsøgte således under mit feltarbejde at undersøge, hvilke tanker de agerende individer gjorde sig i programmet. Under et interview med Oliver, der havde været indskrevet i MTFC i 8 måneder på daværende tidspunkt og snart var færdig med programmets behandling, fortæller han mig om de pointkort, han har med i skolen:

'Jeg synes, de der skolekort er åndssvage. Og så snakkede jeg med dem om, at jeg kunne undgå dem, hvis det bare gik rigtig godt i noget tid. Fordi de ikke rigtig passer på de problemer, jeg har. Så strammede jeg mig ligesom bare an og sådan. [...] Men så viser det sig, at de slet ikke kan komme uden om de kort på nogen måde, fordi de er en fast del af programmet. Det vigtigste det er bare at gøre, som der står ... altså som programmet siger. Ikke hvad der lige giver mening og sådan.' Jeg spørger, hvordan han reagerede på det. 'Jeg ved jo godt, at jeg bliver nødt til at lade, som om det er cool. For ellers kan jeg regne ud, at jeg ikke får mine point.' Synes du, det var cool? spørger jeg. 'Nej, det synes jeg jo ikke ... men jeg glæder mig bare til at være færdig med det her game.'

Oliver lader i dette tilfælde, som om han synes, det er okay, at han alligevel skal fortsætte med skolekort, blandt andet fordi han dermed får point for at være samarbejdsvillig. Der er altså ikke nødvendigvis en forståelse hos Oliver af, at det, han skal gøre for at få point, er det, han synes er retfærdigt eller det rette. Og hvad betyder selve pointene for ham? Han svarer: „Ikke noget. Eller jo, de betyder jo nemlig, at jeg kommer ud af det her [programmet] lidt hurtigere, ikke?"

Det er altså ikke nødvendigvis selve de håndgribelige stimuli, der får Oliver til at „respondere“, som han gør, for at blive i behavioristisk jargon. Som den britiske socialantropolog Edwin Ardener siger: „Menneskelige handlinger er et resultat af et meget kompliceret forløb“ (Ardener 1987:107). Der er mere på spil.

\section{Ukalkulerbar subjektivitet}

Der ligger mere og andet bag de unges handlinger end en indlært higen efter pointene i sig selv. Selv om programmet har en stringent metode og fastlagte retningslinjer, afhænger en stor del af de deltagendes valg og handlinger af mere komplicerede og subjektive bevæggrunde end point. Det er dog ikke kun fra de unges side, at opdragelsesformlens kausalitetskæde kompliceres. Subjektive forståelser og strategiske hensyn påvirker også pointgiverne i programmet, dvs. forældre og træningsforældre. Under mit feltarbejde deltog jeg i et møde med fokus på den unge Søren, hvor det viser sig, at Søren ifølge sit pointskema lige akkurat har nået det antal ugentlige point, programmets struktur har sat som mål for ham. Behandlingskoordinatoren smiler først lidt, hvorefter han siger: 
'Hmm ... det er da heldigt.' Familieterapeuten Eva nikker. Så ryster hun på hovedet og siger: 'Ja, Sørens mor sagde, hun syntes, det var synd for ham [...] når nu han ellers havde prøvet sådan. Så ... ja, hun gav ham vist ekstra point for god opførsel.'

Her indikeres det altså, at Sørens mor har besluttet sig at uddele det, der betegnes som ekstrapoint, ud fra en holdning om, at det ellers ville være synd for hendes søn. Hendes subjektive holdning og moderlige empati får hende således til at give nogle point, hun tilsyneladende ikke ville have givet, hvis hun havde fulgt skemaet stringent. Ligeledes fortæller Lone, træningsmor for den MTFC-indskrevne Kristina, om impulsen til at handle ud fra andre hensyn i pointtildelingen:

\begin{abstract}
'Det er svært, når Kristina ikke har overskud til at lave sine pligter, og jeg så ikke må give hende point, for jeg synes faktisk, hun klarer det meget godt for tiden. Hun er jo en sød pige, og hun prøver altså virkelig. Så føler jeg, at jeg svigter hende.' Jeg spørger Lone, hvad hun mener. 'Jeg kan jo godt forstå, at det hele er lidt svært for hende nogle gange, det ved jeg jo. Og så føler man, at man bare burde kunne tage hensyn, selv hvis det ikke lige lever op til skemaet.' Senere spørger jeg Lone, om disse indskydelser har nogen indflydelse på hendes pointtildelinger. Lone trækker på skuldrene, men svarer: 'Ja, ja. Det kan jo ikke undgås. Altså, hvis der er en god grund til tingene, så kan man jo snakke om det.'
\end{abstract}

Programmets point skal i teorien gives som stimuli for at få den unge til at indlære et bestemt handlemønster, og tildelingen skal derfor følge det fastlagte skema. I den praktiske tildeling findes dog også subjektive, eksempelvis følelsesbaserede, bevæggrunde som for eksempel at tage hensyn til de unge. Træningsmoren Lone giver endda udtryk for, at det ikke kan undgås at inddrage disse i arbejdet med den unge. Som sociologen Kjeld Høgsbro har pointeret, viser undersøgelser, at de fleste praktikere på det sociale område modificerer og tilpasser de evidensbaserede metoders oprindelige koncept til lokale forhold og individuelle forskelle (Høgsbro 2010:21). MTFC er skabt med forventningen om, at behandlingen skal udføres lineært, som manualerne foreskriver, men denne stringens er ikke mulig at overføre fuldt ud i praksis. Der ligger en forestilling om en kontrolleret, rationel og programmeret opdragelse og udvikling i programmet. En behandlingsformel, hvor der er „styr på det hele“. I praksis har socialt arbejde afsæt i nogle langt mere komplicerede sociale forhold og sammenhænge end det, der kan redegøres for kausalt i form af et direkte årsag-virknings-forhold. Oliver opfører sig på en bestemt måde og „lader som om“, blandt andet fordi han kan regne ud, at han kan få de nødvendige point, der skal til, for at komme hurtigt ud af programmet. En af træningsforældrene karikerede MTFC's behavioristiske ophav på følgende vis: „Det er ligesom det der tv-program 'Det er mig eller hunden'. De har en rigtig møgkøter, men så får den belønning for god opførsel, og så får man en 
sød hund." Men deltagerne i programmet er selvfølgelig ikke hunde, og der ligger derfor en langt mindre stringent sammenhæng bag deres ageren. Vi kan se, at subjektive bedømmelser har en stor betydning for uddelingen af point, men derudover kompliceres behandlingsprogrammet også af modsatrettede forståelser af opdragelse i forhold til henholdsvis behandlingsindskrevne unge og unge $i$ almindelighed.

\section{Opdragelse til lydighed eller selvstændighed}

MTFC's metode er bygget på forskningsresultater, og dets effektivitet afhænger af, at der bruges nogle håndgribelige incitamenter i form af point, som forskning har vist fungerer bedst $\mathrm{i}$ forhold til målgruppen af utilpassede unge. Behaviorisme er som beskrevet grundlaget for opdragelsesformen i behandlingen af de indskrevne unge. Denne opdragelsestilgang viste sig i feltarbejdet at være i strid med den tilgang, træningsforældrene havde til opdragelsen af deres egne børn. Den norske antropolog Marianne Gullestad har studeret de moderne familieformer i de nordiske lande, og i bogen Family and Kinship in Europe påpeger hun, at der $\mathrm{i}$ moderne nordisk opdragelsesideologi findes en modsætning mellem det at ,være sig selv“ og det at „være lydig“. At være sig selv anses for positivt, hvorimod det at være lydig, som ellers har været centralt i vestlig opdragelsesideologi tidligere og stadig er det flere steder, nu anses som noget, der kan være negativt. Man må ikke være for lydig (Gullestad 1997:208). Gullestad sammenkobler dette med, at der er kommet øget fokus på det positive ved individualisme, og påpeger, at barnet dermed i højere grad lærer, at dets personlige holdning er vigtig og derfor også kan influere beslutninger i hjemmet: „Videregivelse af moralske værdier har ændret sig fra påbud om lydighed til indflydelse gennem overtalelse og komplicerede forhandlinger" (op.cit.215). Man skal være sig selv og ikke blot gøre, som andre (for eksempel forældre eller andre autoriteter) beder en om at gøre. Gullestad uddyber:

For at leve op til ideen om at være sig selv skal børn legitimere deres værdier i form af deres egne individuelle overbevisninger og præferencer, ikke i form af de overbevisninger og præferencer, deres forældre har. Forældre i dag skal ideelt set videregive evnen til at være sig selv og udvikle sig selv til deres børn i stedet for at videregive konkrete ideer og værdier (ibid.).

At opdrage børn kommer med denne ideologi til at bestå i at få børnene til selv at vælge at opføre sig på bestemte måder gennem selvets indrestyring frem for en forældrebaseret ydrestyring. For at børnene får mulighed for at lære dette på hensigtsmæssig vis, kan forældre stille nogle rammer og begrænsninger op for 
deres børn. Ideen er dog, at børnene derefter selv bestemmer inden for disse rammer. Denne tendens ses også hos træningsfamilierne i MTFC, når det gælder opdragelsen af deres egne børn, dvs. de børn, de har ansvar for, som ikke er programanbragt. En træningsfar sætter følgende ord på sin private holdning til opdragelse:

De får selv lov til at bestemme meget af det, de gør, og det synes jeg er det rigtige at gøre. Så kan de lære mere ... Altså ikke bare at gøre, som vi [forældrene] gør. Så jeg går klart ind for frihed under ansvar.

Mange af de andre træningsforældre i mit feltarbejde giver ligeledes udtryk for, at de gerne vil opdrage deres børn til, som træningsmor Lotte beskriver det, ,at kunne tænke selvstændigt og forstå, hvad der er rigtigt og forkert“. Forældrene vil således gerne lære deres børn at tage de ,rigtige“ beslutninger, uden at det er forældrene, der tager dem for dem. Gullestad skriver: „Forældre synes ofte, det er forkert, hvis børn og unge holder sig til forældrenes værdier udelukkende for at behage dem" (Gullestad 1997:216). Lottes mand, Niels, forklarer, hvordan han har forsøgt at lære sin datter, hvorfor hun skal gøre bestemte ting, frem for at hun bare skal gøre dem:
'Hvis jeg sagde til Mie [Niels' datter], at hun skulle et eller andet, så kunne hun godt finde på sådan at udfordre det og spørge hvorfor, fordi vi altid har haft ret frie rammer for vores børn. Men altså, hvis man i stedet kan forklare hende, hvad man synes, og tale med hende om det, så er det jo endnu bedre.' Jeg spørger, hvorfor det er bedre. 'Jo, så gør hun det, fordi hun selv forstår, at det er det rigtige at gøre, jo.'

Forældrene i disse eksempler ser gerne, at deres børn selvstændigt forstår, hvad der er rigtigt at gøre ud fra samtale og ,frie valg“ frem for at gøre noget, udelukkende fordi deres forældre har bedt dem om det. På den måde ønsker forældrene at lære deres børn at forstå sammenhænge og sociale hentydninger, så de kan finde deres egne måder at agere hensigtsmæssigt på. Træningsfaren Esben fortsætter dog efter at have forklaret om den opdragelse, han ynder at give sine egne børn:

'Men de unge [MTFC-deltagere], de skal jo styres lidt. Vi snakkede med børnene om, at det var nogle svære unge, der ville komme. Så vi skulle være forberedt på lidt af hvert, og de skulle forstå, at vi derfor bliver nødt til at gøre det [opdragelse] anderledes med dem.' Frederik, den unge mand, der er anbragt hos Esben, kommer i samme øjeblik ud ad døren til os, hvor vi sidder på terrassen. 'Må jeg egentlig godt tage med til den der fødselsdag i min klasse?' spørger Frederik. 'Ja,' svarer Esben, 'det må du da gerne, hvis du har lyst.' Frederik smiler. Esben hælder mere kaffe op, men tilføjer pludselig: 'Eller nåh, vi skal faktisk lige have det godkendt som noget, du må.' 
Der findes en klar tendens blandt træningsforældrene til at opdrage deres egne børn til at tage selvstændige beslutninger, men de ved alle, at deres rolle som opdragere i MTFC er anderledes. Dette sidste eksempel viser kompleksiteten $i$ at befinde sig imellem de to opdragelsesideologier. Esben glemmer et kort øjeblik, at de unge MTFC-deltagere ifølge programmets forskrifter skal opdrages til lydighed og „styres“ til forskel fra ens egne børn. Opdragelsestilgangen i MTFC afspejler således ikke nødvendigvis en generel idealopdragelse, men et ideelt kausalitetsmønster efter programmets standard. Programmet har principielt ingen ideologi om læringsaktiviteter med henblik på at opøve en opførsel, som afspejler en form for individuel moralsk eller „fornuftig“ tænkning. Programmet og dermed behandlingen er omhyggeligt planlagt og den ønskede adfærd identificeret og defineret, hvorefter man så opøver den unge i den ønskede respons. Opdragelsesformen er træning $i$ at fremkalde den ønskede adfærd med brug af point som belønning. Fordi dette ideal afviger fra både de unges, træningsforældrenes og de biologiske forældres gængse forestillinger om opdragelse, bliver praktiseringen af programmet farvet af en ambivalens. Når man ser på MTFCinterventionens principielle indhold i samspil med praksis, er der generelt en langt højere grad af uforudsigelighed til stede end det, der umiddelbart lægges op til i et evidensbaseret program, hvor der er en forventning om stringens, klarhed og målbarhed. Den antropologisk interessante pointe er, at de stiltiende kulturelle forestillinger om opdragelse påvirker praksis på gennemgribende vis. I takt med at behandlingen søger at afspejle de unges nærmiljø og langt hen ad vejen består af hverdagsaktiviteter, der udføres i en kontekst, der spejler almindelige sammenhænge uden for behandlingsregi, rummer behandlingsprocessen et træk af imitation. Men som de svenske socialforskere Anders Bergmark og Lars Oscarsson pointerer i forbindelse med en diskussion af misbrugsbehandling, forudsætter tilstræbt autenticitet en tilstand af ikke-autenticitet (Bergmark \& Oscarsson 2006:211). Teorien i MTFC bygger på en antagelse om, at den unge kan indøve hensigtsmæssige mønstre for udførelsen af hverdagsaktiviteter i et miljø, der ligner den unges almindelige hverdagsmiljø hjemme, men som er struktureret og monitoreret igennem læringsprocessen. Men det er tydeligt for såvel udøvere, familier og de unge i programmet, at de behandlingsmæssige rammer ikke er som et almindeligt dagligliv uden for behandlingsregi - tænk blot på Olivers betegnelse af programmet som ,et game“. De unge får roller og rammer i træningsfamilierne, der tydeligt adskiller sig fra hverdagskutymen for familiens egen hverdagspraksis og opdragelsesmønstre. Den anbragte unge er i familien, netop fordi han/hun ikke selvstændigt gør, som familiemedlemmerne i træningsfamilien gør, og han/hun er der dermed i kraft af sin manglende lighed med dem og deres hverdagspraksis. I forsøget på at træne eller opdrage den 
unge til det tilstræbte adfærdsmønster og dermed en social position som ikkeafvigende markerer behandlingssammenhængen samtidig, at han eller hun netop er afvigende. Den unge skal trænes og monitoreres for at gøre, som medlemmerne af træningsfamilien gør uden at behøve behandling. Der skabes på denne måde en imitation af, at den unge programdeltager deltager i et almindeligt hverdagsliv, men med en tydelig og eksplicit forståelse af, at den unge ikke er i stand til at deltage på den forventede måde uden hjælp og regelfaste rammer. Så hvad sker der, når behandlingsprogrammet slutter, og den unge ikke længere har disse nødvendige rammer? Ideelt set har den unge på dette tidspunkt lært at agere som tilsigtet uden rammerne, men selv i programmets afslutningsfase kalder Oliver behandlingen for et game og tydeliggør imitationsfaktoren og dermed forskellen mellem sine egne handlinger, tanker og forståelser og det, som programmet har pålagt ham gennem behandlingen.

\section{Evidens for hvad?}

I evidenssammenhænge betragtes det randomiserede kontrollerede forsøg (RCT) ofte som ,den gyldne standard“ $\mathrm{i}$ forhold til at undersøge interventioners effekt. Fortalere for MTFC-behandlingen lægger som oftest vægt på netop det, at programmet gentagne gange er blevet RCT-evalueret med positive resultater (Fisher \& Chamberlain 2000:161). Med undtagelse af et svensk studie fra 2010 er alle de gennemførte RCT-undersøgelser dog udelukkende fra USA og foretaget $i$ en amerikansk kontekst og oftest af forskere med tilknytning til programmet (for eksempel Chamberlain, Moreland \& Reid 1992; Chamberlain \& Reid 1998; Eddy \& Chamberlain 2000). I Danmark findes der endnu ikke systematiske registreringer af programmets effekt.

RCT-studier forudsætter, at den undersøgte intervention er veldefineret, standardiseret og reproducerbar, og at den givne intervention er administreret på eksakt samme vis til hver enkelt deltager. Dette er en udfordring for evidensbaserede behandlingsprogrammer, idet interventionerne varierer $\mathrm{i}$ forhold til individerne $\mathrm{i}$ dem samt baggrunden og dynamikken i den organisatoriske kontekst (Gray, Plath \& Webb 2009:32). Som antropolog Morten Hulvej Rod pointerer i forbindelse med evidens i forebyggelsesregi, bliver det forskningens opgave at svare på, om praksis virker eller ikke virker, ved at betragte interventionen som bestående af objektive og målbare forhold, der holdes sammen af kausale mekanismer. Ud fra et antropologisk perspektiv må forebyggelse (og socialt arbejde) dog forstås som en intervention i sociale snarere end kausale relationer (Rod 2010:51). De randomiserede forsøg fra USA viser, at den evidensbaserede behandling i MTFC har en hensigtsmæssig effekt, men siger ikke noget om, hvilke elementer af 
behandlingen der er katalysator for forandringen. Principielt kunne det således være netop afvigelserne fra behandlingsmanualen og skemaerne, der skaber effekten. Endnu en vigtig begrænsning for et RCT-studie af en social intervention er, at de ønskede resultater af interventionen skal være målbare. Det er dog en almen forståelse, at mange sociale, emotionelle og menneskelige karakteristika er vanskelige at måle. Behandling i socialt arbejde, uagtet om det er evidensbaseret eller ej, handler om, hvordan man interagerer med hinanden. I den forbindelse opstår der nogle modsætninger og en ambivalens, når man som pleje- eller træningsforældre kun skal se på adfærd, og som ung kun bliver bedømt på adfærd. Det kan man ikke. Det er både praktisk og ideologisk umuligt, blandt andet fordi der hersker andre opdragelsesmæssige idealer og forestillinger i den danske kultur. I MTFC-programmet forholder manualen sig eksplicit til point og skemaer, men ikke til den sociale og subjektive betydning af opdragelse og opførsel. Dette tyder på, at der i det evidensbaserede behandlingsprogram figurerer en overbevisning om, at praksis godt kan formes efter en ønsket model eller metodeformel, der kan sikre effektivitet. Dette kan ses som et udtryk for en interventionsoptimisme, hvor antagelsen er, at virkeligheden, hvilket i socialarbejdet er praksisplanet, både kan formes og i vid udstrækning også forudses. Netop dette er en af byggestenene for den evidensbaserede praksis.

Hvis vi vender tilbage til indledningens første spørgsmål, kan vi konkludere, at behavioristisk adfærdsregulering på ny har vundet indpas i socialt arbejde $\mathrm{i}$ Danmark, blandt andet på grund af den tiltrækningskraft, der ligger i, at behandlingsmetoderne er målbare og reproducerbare - og dermed også kan gøres til genstand for effektstudier. Evidens i socialt arbejde har til hensigt at kunne dokumentere effekten af interventioner. Denne dokumentation skal skabe grundlaget for udarbejdelsen af blandt andet interventioner, forvaltning og praksis med afsæt $\mathrm{i}$ viden om, hvilke indsatser der virker, og hvilke der ikke virker. Med baggrund i en sådan viden skaber man således behandlingsformer, der bygger på metoder, som man med baggrund $\mathrm{i}$ den fundne evidens forventer vil have en bestemt effekt, mere eller mindre uafhængigt af den konkrete sociale og kulturelle kontekst. Behandlingen og anbringelsen af udsatte unge har i løbet af de seneste år været et omdiskuteret emne i forskningsregi og i de danske medier, hvor både plejefamilier og døgninstitutioner har været udsat for kritik. Kritikken har blandt andet drejet sig om, at der ikke ,fås nok for pengene“ forstået på den måde, at indsatserne ikke menes at have tilstrækkelig effekt $i$ forhold til at holde unge fra for eksempel kriminalitet og misbrug (for eksempel Schøtt 2013; Gaardmand 2014). De evidensbaserede interventioner er imidlertid blevet udbredte. Både i kommuner og stat findes der en udbredt tillid til evidensbaserede metoder og effekten af disse på trods af mangel på danske effektmålinger. Mange midler bliver kanaliseret i 
den retning, og der synes at være en tro på, at de evidensbaserede interventioner er svaret på kritikken af området. Hvis vi bevæger os videre til indledningens andet og tredje spørgsmål om, hvordan adfærdsregulering implementeres i praksis, gjorde feltarbejdet blandt programdeltagerne det tydeligt, at uforudsigeligheden i menneskelig ageren inddrager afvigelser i selv de mest regelstyrede domæner. Den evidensbaserede behandling virker til en vis grad. De amerikanske RCTstudier peger på, at behandlingen blandt andet sænker kriminalitetsraten, forbedrer relationsmønstre og resulterer $i$, at en større procentdel af de behandlede unge kommer i arbejde (Fisher \& Chamberlain 2000:162). Men behandlingen udføres ikke i praksis på den stringente og reproducerbare måde, som programmet principielt lægger op til og bygger sin evidensbasering på. Subjektivitet, kulturelle forståelser og personlige strategier påvirker behandlingsformen betydeligt og gør kausaliteten bag programmets effektivitet uklar. Man må derfor inddrage disse mere dynamiske og komplekse aspekter i forståelsen og evalueringen af et behandlingsprogram og dets effekt og betydning - ikke kun det definerede „evidente“ årsag-virknings-forhold.

\section{Evident behandling?}

Behandling i socialt arbejde har til formål at normalisere det afvigende. Som socialforsker Tine Egelund og antropolog Turf Böcker Jakobsen har pointeret, er normaliseringens centrale placering i socialt arbejde ikke ensbetydende med, at der hersker konsensus om en enkelt tilstræbelsesværdig normalitet eller en bestemt behandlingsform, der kan opnå den, og derfor er der plads til uenigheder om både normaliseringens mål og midler (Egelund \& Jakobsen 2006:20). Artiklen her har haft til formål at åbne for en diskussion af det evidensbaserede behandlingsarbejde som en behandlingsform, der blot er et bud af mange, men som med sin metode og tilgang adskiller sig fra andre bud på behandlingsformer ved at være betegnet som evidensbaseret.

Evidenstænkningen i sig selv er umiddelbart enkel og ,uskyldig“ forstået på den måde, at det er en metode, der ligesom andre metoder har fordele og ulemper. Der følger dog nogle antagelser med, når man anvender evidensbaseret behandling. For eksempel findes der en grundforståelse af, at virkeligheden er repetitiv, at social praksis kan styres, at kontekst ikke har den store betydning, og at kulturelle forhold ikke har betydelig relevans - hvis man bare følger metoden. Disse antagelser ekspliciteres ikke, og derfor indebærer evidensbaseret behandling en bestemt implicit virkelighedsforståelse. Al form for viden, også den antropologiske, er baseret på antagelser og derfor begrænset. Man kan som følge af disse begrænsninger spørge sig selv, om betegnelsen evident behandling er misvisende. 
Feltarbejdet blandt brugere og udøvere af MTFC peger på et signifikant misforhold mellem det evidensbaserede behandlingsprograms teori og praksis og en betydelig uklarhed omkring behandlingens effekt efter endt programdeltagelse. Det er programmets formål, at de unge deltagere skal resocialiseres til et samfundsliv uden behandlingsrammer, men eftersom behandlingens præmis er, at netop de strukturerede rammer er grundlaget og motivationen for den normaliserende effekt, er manglen på opfølgning slående.

Søgeord: socialt arbejde, evidensbaseret behandling, opdragelse, behaviorisme, MTFC

\section{Litteratur}

Ardener, Edwin

2007 [1989] The Voice of Prophecy. Further Problems in the Analysis of Events. In: M. Chapman (ed.): The Voice of Prophecy and Other Essays. Pp. 134-54. Oxford: Basil Blackwell.

Bergmark, Anders \& Lars Oscarsson

2006 Indhold, kontekst og det personlige valg ved behandling af misbrug. I: T. Egelund \& T. Böcker Jakobsen (red.): Behandling i socialt arbejde. Begreb og praksis.

Side 199-215. København: Hans Reitzels Forlag.

Chamberlain, Patricia

2003 The Oregon Multidimensional Treatment Foster Care Model. Features, Outcomes, and Progress in Dissemination. Cognitive and Behavioral Practice 10(4):303-12.

Chamberlain, Patricia, Sandra Moreland \& Kathleen Reid

1992 Enhanced Services and Stipends for Foster Parents. Effects on Retention Rates and Outcomes for Children. Child Welfare 71(5):387-401.

Chamberlain, Patricia \& John Reid

1998 Comparison of Two Community Alternatives to Incarceration for Chronic Juvenile Offenders. Journal of Consulting and Clinical Psychology 6(4):624-33.

Chapman, Malcolm

2007 Introduction. In: M. Chapman: The Voice of Prophecy and Other Essays. Pp. xvi-xxxvi. Oxford: Berghahn Books.

Eddy, J. Mark \& Patricia Chamberlain

$2000 \quad$ Family Management and Deviant Peer Association as Mediators of the Impact of Treatment Condition on Youth Antisocial Behaviour. Journal of Consulting and Clinical Psychology 68(5):857-63

Egelund, Tine \& Turf Böcker Jakobsen

2006 Behandlingsbegrebet i socialt arbejde. I: T. Egelund \& T. Böcker Jakobsen (red.): Behandling i socialt arbejde. Begreb og praksis. Side 13-27. København: Hans Reitzels Forlag.

Eriksen, Thomas Hylland

2001 Small Places, Large Issues. An Introduction to Social and Cultural Anthropology. London: Pluto Press. 
Fisher, Philip \& Patricia Chamberlain

2000 Multidimensional Treatment Foster Care. A Program for Intensive Parenting, Family Support, and Skill Building. Journal of Emotional and Behavioural Disorders 8(3):155-64.

Gilliam, Laura \& Eva Gulløv

2012 Samfundets børn. Civilisering, barnesyn og institutionalisering. I: L. Gilliam \& E. Gulløv (red.): Civiliserende institutioner. Om idealer og distinktioner i opdragelse. Side 39-62. Aarhus: Aarhus Universitetsforlag.

Grey, Mel, Debbie Plath \& Stephen Webb

2009 Evidence-based Social Work. A Critical Stance. Routledge: London.

Gullestad, Marianne

1997 From "Being of Use" to "Finding Oneself". Dilemmas of Value Transmission Between the Generations in Norway. In: M. Gullestad \& M. Segalen (eds.): Family and Kinship in Europe. Pp. 202-18. London: M. Pinter.

Gaardmand, Nola Grace

2014 Kritik. Uddannelse af plejefamilier sejler. Jyllands-Posten 6. april.

Henriksen, Louisa Ellen

2014 Familier på formel. Et studie af familieforståelse og familiepraksis i et evidensbaseret behandlingsprogram. Speciale. København: Institut for Antropologi, Københavns Universitet.

Høgsbro, Kjeld

2010 Evidensbaseret praksis - forhåbninger, begrænsninger og muligheder.

Tidsskrift for Forskning i Sygdom og Samfund 15:11-30.

Krogstrup, Hanne

2011 Kampen om evidens. Resultatmåling, effektevaluering og evidens.

København: Hans Reitzels Forlag.

Oakley, Ann

2000 A Historical Perspective on the Use of Randomised Trials in Social Science Settings. Crime and Delinquency 46(3):315-29.

Rieper, Olaf \& Hanne Foss Hansen

2007 Metodedebatten om evidens. Hentet 22. februar 2013. www.akf.dk/udgivelser.

Rod, Morten Hulvej

2010 Evidenssproget. Om sprog, viden og virkning i forebyggelse. Tidsskrift for Forskning i Sygdom og Samfund 15:31-54.

Schøtt, Niels Jacob

2013 Hård kritik. Landets døgninstitutioner svigter deres ansvar. Udgivet 27. maj. Hentet 14. april 2015. www.dr.dk/Nyheder/Indland/2013/05/24/141759.htm.

Wampold, Bruce

2001 The Great Psychotherapy Debate. Models, Methods and Findings. Psychology in the Schools 40(6):701-02. 
